\title{
The 8th International Conference on Coastal Dynamics, Helsingør, Denmark, 12-16 June, 2017
}

\author{
Troels Aagaard ${ }^{1}$ - Aart Kroon ${ }^{1}$. David R. Fuhrman ${ }^{2}$ \\ Published online: 25 November 2019 \\ (C) Springer-Verlag GmbH Germany, part of Springer Nature 2019
}

The coastal zone is amongst the most dynamic environments on the planet, but it is also facing great, and increasing, natural and anthropogenic pressure. This calls for better tools of prediction of coastal change. The inaugural Coastal Dynamics conference was held in 1994 in Barcelona, Spain, in response to the appearance of large field and laboratory data sets with which to test and validate numerical prediction tools.

Since then, the international Coastal Dynamics conference series has become one of the most important meetings for scientists within the fields of nearshore dynamics and coastal evolution. After the meeting in Barcelona, conferences were held in Gdansk, Poland (1995); Plymouth, UK (1997); Lund, Sweden (2001); Barcelona (2005); Tokyo, Japan (2009); and Arcachon, France (2013). The Coastal Dynamics conference series advances the community's understanding of recent basic and applied research concerning coastal waves and currents; interactions between wind, water, and sediments; and morphological changes in different environments (with and without structures) such as sandy, rocky, and muddy coasts, inlets, and estuaries. The conference documents research and applications treating these coastal dynamics at the short, medium, and large/long spatial and temporal scales of the climatic drivers and coastal responses.

The 8th International Conference on Coastal Dynamics was held on June 12-16, 2017, in the city of Helsingør

Responsible Editor: Jörg-Olaf Wolff

Troels Aagaard

taa@ign.ku.dk

1 Department of Geosciences and Natural Resource Management, University of Copenhagen, Øster Voldgade 10, DK-1350 Copenhagen K, Denmark

2 Department of Mechanical Engineering, Fluid Mechanics, Coastal \& Maritime Engineering Section, Technical University of Denmark, Nils Koppels Alle, Building 403, DK-2800, Kgs Lyngby, Denmark
(Elsinore), Denmark. It was hosted jointly by the University of Copenhagen, the Danish Hydraulic Institute (DHI), the Technical University of Denmark (DTU), and the Danish Coastal Authority (DCA), and it was chaired by Per Sørensen, Aart Kroon, and Troels Aagaard. The conference was attended by 233 researchers from 23 countries. A total of approximately 300 abstracts were submitted for presentation at the conference and after peer review and selection by the international technical abstract committee, the conference comprised 143 oral and 37 poster presentations. The presentations were all associated with a full paper, which was published electronically in the conference proceedings volume.

During the conference, three keynote lectures were presented by Dr. Edward Anthony, Dr. Peter Nielsen, and Dr. Nils Drønen. The conference also comprised two short courses on Shoreline Evolution Modelling and Climate Change and Coastal Adaptation, and a field trip was organized along the beaches of the North Zealand coast. The conference dinner was held at Hotel Marienlyst in Helsingør where the international organizing committee honoured Prof. Rob Holman with the Coastal Dynamics 2017 coastal award for his long and significant contribution to the field of coastal science.

Before the conference, delegates were invited to contribute a full journal paper for publication in the Topical Collection in Ocean Dynamics. Amongst the positive respondents, 18 papers were selected on the basis of the impression made during the oral/poster presentation, the quality of the conference paper, and the scores/reviews from the abstract review committee. Following peer review and revision, 11 papers were finally included in this topical collection.

The first three papers to be discussed consider coastal dynamics related to tidal dunes, shoreline evolution, and the swash zone. Doré et al. (2018) investigate tidal dune dynamics based on field observations, which show superimposed ripples on larger scale tidal dunes. Numerical modelling based on a 2D RANS (Reynolds-Averaged Navier-Stokes) approach is applied at both small (ripple) and large (dune) scales, and in both cases, simulation results are reported to compare well 
with field observations. Falqués et al. (2018) report on a new morphological instability mechanism, predicted to occur in the framework of one-line shoreline modeling when waves approach the coastline at large incidence angle. A 2DH (two horizontal dimension) model resolving surf zone instabilities is then utilized to investigate whether this may be related to observable natural phenomenon, concluding that it would approximate a real morphodynamic instability only for quite particular conditions. Hughes et al. (2018) investigate swash saturation based on an extensive field data set, representing the full range of microtidal beach states (reflective, intermediate, and dissipative). Two different models are tested, driven either by standing waves or bores. Both models are reported to broadly predict the general behaviour of swash saturation evident in the data, but neither is sufficiently accurate in detail, thus clarifying the need for further research to accurately determine limiting swash heights on natural beaches.

Three papers deal with sediment transport and coastal morphodynamics on short timescales. Petrotta et al. (2018) report on a series of small-scale laboratory experiments to investigate wave ripple formation on a sloping sand bed subjected to regular and random waves. They find that a sloping bed strongly affects ripple shape and migration speed compared with ripples developing on a horizontal bed. Almar et al. (2018) use the wave-phase-resolving SWASH model to investigate the effects of reflection from irregular swash zone morphology on surf zone dynamics. They find that the irregular reflection creates a standing wave that resembles a subharmonic edge wave and they suggest that wave reflection over steep beaches could be a mechanism for the development of rhythmic morphological features. Finally, Ruiz de Alegria-Arzaburu and Vidal-Ruiz (2018) report field observations of beach recovery after an El Niño winter on a beach in Mexico. They show that the energetic winter waves caused large offshore bar migration and a substantial loss of sand from the subaerial beach and conclude that the amount of beach recovery during spring seasons depends on the strength of winter wave conditions.

Another three papers deal with larger scale morphodynamics on beaches. Kaczkowski et al. (2018) are presenting the dune growth at two sites after major beach nourishments and describe the additional value of this dune formation for coastal protection. Lemos et al. (2018) use a decadal data set of monthly beach profiles at a macro-tidal beach in France, together with an empirical model to unravel the drivers behind the beach evolution. Arriaga et al. (2018) focus on the formation events of shoreline sand waves on gravel beaches. They describe two formation events and they conclude that the undulations are self-organized and that the underlying formation mechanism is the high-angle wave instability.

The final two papers deal with morphological evolution of sand flats. Benninghoff and Winter (2018) report on the decadal evolution of tidal flats and channels in the Outer Weser estuary in Germany. They conclude that the Outer Weser estuary is not in an equilibrium state for the investigated period, and tidal flats accreted with a rate exceeding the local mean sea level rise. Silva et al. (2018) are presenting field measurements and a cellular automata model to study the influence of groundwater depth on coastal dune development and sand flats close to inlets. Their model results are in line with the field observations and they concluded that groundwater is capable of introducing spatial variability in dune growth.

\section{References}

Almar R, Lerma AN, Castelle B, Scott T (2018) On the influence of reflection over a rhythmic swash zone on surf zone dynamics. Ocean Dyn 68:899-909

Arriaga J, Falqués A, Ribas F, Crews E (2018) Formation events of shoreline sand waves on a gravel beach. Ocean Dyn 68:735-748

Benninghof M, Winter C (2018) Decadal evolution of tidal flats and channels in the Outer Weser estuary, Germany. Ocean Dyn 68: $1181-1190$

Doré A, Bonneton P, Marieu V, Garlan T (2018) Observation and numerical modeling of tidal dune dynamics. Ocean Dyn 68:589-602

Falqués A, Kakey N, Calvete D (2018) A new instability mechanism related to high-angle waves. Ocean Dyn 68:1169-1179

Hughes MG, Baldock TE, Aagaard T (2018) Swash saturation: an assessment of available models. Ocean Dyn 68:911-922

Kaczkowski HL, Kana TW, Traynum SB, Visser R (2018) Beach-fill equilibration and dune growth at two large-scale nourishment sites. Ocean Dyn 68:1191-1206

Lemos C, Floc'h F, Yates M, Le Dantec N, Marieu V, Hamon K, Cuq V, Suanez S, Delacourt C (2018) Equilibrium modeling of the beach profile on a macrotidal embayed low tide terrace beach. Ocean Dyn 68:1207-1220

Petrotta C, Faraci C, Scandura P, Foti E (2018) Experimental investigation of sea ripple evolution over sloping beaches. Ocean Dyn 68 : $1221-1237$

Ruiz de Alegria-Arzaburu A, Vidal-Ruiz JA (2018) Beach recovery after El Niño 2015-2016 at Ensenada Beach, Northern Baja California. Ocean Dyn 68:749-759

Silva FG, Wijnberg KM, De Groot AV, Hulscher SJMH (2018) The influence of groundwater depth on coastal dune development at sand flats close to inlets. Ocean Dyn 68:885-897 